\title{
MULTICULTURAL ENCOUNTERS ON STAGE: THE USE OF JAVANESE CULTURAL ELEMENTS BY THE SURINAMESE DOE-THEATRE COMPANY
}

\section{Annika Ockhorst}

In 1974 the Surinamese journalist and writer Thea Doelwijt and actor and director Henk Tjon founded the Doe-theatre company in Suriname. ${ }^{1}$ They met each other in 1970 during the production of the satirical cabaret Frrrek ('Shit'). In 1972 they coproduced the play Hare Lach, ${ }^{2}$ followed in 1973 by Land te koop (Land for Sale). All three successful theatre productions were characterized by a socially-critical view on Surinamese society. In Surinamese theatre, the focus on Surinamese society was a relatively new phenomenon. Official theatre, as well as broader cultural life in the Dutch colony, had been founded on European standards and represented European society. From the second half of the twentieth century on, Creole cultural nationalism inspired a reorientation in theatre. Local play writers emerged and gradually their plays focused more on Surinamese society and the various cultures in it.

The Doe-theatre company was an exponent of this reorientation in Surinamese cultural life from Europe to Suriname. By founding their own theatre company, Doelwijt and Tjon hoped to establish and produce a new Surinamese form of theatre on a structural basis. They had three aims. First, by casting a socially critical view on Surinamese society and contemporary events, the Doe-theatre plays were meant to raise awareness among their audience. The plays were characterized by a sharpness

\footnotetext{
1 To a large extent, this chapter has been based on my MA thesis 'S.O.S. W'e g'a fesi. Een onderzoek naar de weerspiegeling van de Surinaamse samenleving in het werk van het Doe-theater, 1970-1983'. This thesis was written under supervision of Dr P.J.J. Meel. It has recently been transformed into the book Lachen, huilen, bevrijden: De weerspiegeling van de Surinaamse samenleving in het werk van het Doe-theater, 1970-1983 (Laughing, crying, liberating: The reflection of Surinamese society in the work of the Doe-theatre company, 1970-1983) (Ockhorst 2012).

2 Hare Lach is a satirical reference to both Hare Krishna and the Hindustani political leader Jagernath Lachmon.
} 
that was uncommon in the Surinamese context. This sharp tone can be attributed to Doelwijt and her upbringing in the Netherlands. Second, the founders of the Doe-theatre company strove for professionalism. Tjon, who had received a formal theatre education in the Netherlands, was determined to elevate the practice of theatre in Suriname to a higher level, from a hobby on the side to a full-time profession. Doe-theatre members were obliged to follow the intensive theatre training created by Tjon himself. This training was based on Suriname's own cultural richness and used traditional songs, instruments, dances, rituals and oral traditions of all Surinamese population groups. Third, the Doe-theatre company was meant to have a multicultural and truly Surinamese character. Cultural nationalism had inspired Doelwijt and Tjon to explore and rediscover the various non-European cultures in Suriname, which had been marginalized by centuries of Dutch colonialism. In their plays, they emphasized Suriname's own cultural richness. In order to raise more mutual understanding among the ethnically divided Surinamese population, Doelwijt and Tjon included traditional elements of all Surinamese cultures in the Doe-theatre plays. These three aims - social criticism, professionalism and a multicultural Surinamese character - were combined in a form of total theatre, consisting of play, song, music and dance, in a way that was new to Suriname.

\section{Javanese in Suriname}

Through Dutch colonialism, Suriname has acquired a greatly diverse population. Currently, the Hindustani community, brought to Suriname by contract labour, forms the largest population group (27.4\%). Second place is taken by the Creole community (17.7\%), who are descended from the enslaved Africans that worked the Surinamese sugar and coffee plantations. In third place we find the descendants of those slaves who had fled the plantations and formed new communities in the interior, commonly referred to as Maroons (14.7\%). Then, just outside of the top three, comes the Javanese community (14.6\%). Like the Hindustani people, the Javanese were brought to Suriname through contract migration. Between 1890 and 1939, a total of 32,986 contract labourers migrated from Java to Suriname. Around a quarter of them returned to Java after the end of their contracts. The majority of Javanese stayed in Suriname, forming a Javanese community that today consists of more than 70,000 people. 
On a Surinamese population of only 492.829 this means that the Javanese community in Suriname is indeed large. ${ }^{3}$

The Javanese community in Suriname held on firmly to its Javanese traditions. Living and working conditions on the plantations were tough and the Javanese workers were fairly isolated from other ethnic groups. Because of this, a strong sense of community arose among the Javanese labourers, who shared a common nostalgia for Java. The Javanese culture these labourers brought with them to Suriname, was not Javanese 'high culture'. Most of the labourers were illiterate youth from a low socioeconomic background, who continued daily life - and the traditions in it - as they knew it. The few people with more extensive knowledge of traditions and religion were promoted to experts. Thus, various types of traditional songs, music and dance from daily life were preserved by the Surinamese-Javanese community, although often influenced by their new environment.

The preservation of Javanese culture in Suriname was also facilitated by plantation owners who allowed the organization of traditional Javanese 'entertainment' such as slametans and wayang performances. By allowing these traditional forms of entertainment, plantation owners hoped to counter the problem of widespread opium use and gambling addiction among the Javanese workers. During the 1930s the preservation of Javanese culture was also stimulated by Governor Kielstra. As a means to counter the economic crisis, Kielstra planned to turn the Surinamese districts into 'Asian' territories, where small farming would take over from the poorly run plantation economy. To prevent the Hindustani and Javanese famers from leaving the countryside, they were to feel at home in these new Asian districts. Kielstra's plans failed due to World War Two. From the end of the war on, slowly, Javanese started leaving the countryside in search of jobs in the bauxite industry and in the city. Interaction between the Javanese and other population groups grew and affected the way Javanese youth viewed traditional Javanese culture. 'Traditional' was deemed 'old-fashioned', as the Javanese youth wished to be (creolized) Surinamese rather than Javanese. Efforts to counter this development and preserve Javanese culture in Suriname were made by Indonesian repre-

\footnotetext{
3 Current population numbers and percentages are derived from the 2004 census. They can be found on http://nl.wikipedia.org/wiki/Surinamers. The numbers for migrated and remigrated Javanese contract labourers were derived from Parsudi Suparlan (1995).
} 
sentatives and, later on, by the Indonesian embassy, actively promoting traditional and more modern aspects of Javanese culture in Suriname.

Despite the efforts to preserve Javanese cultural expressions in Suriname, some of them lost their audience and are no longer performed on a regular basis. This is the case, for example, with the wayang wong performances. Dance styles that are still commonly practiced in Suriname are the tayub dance of the lèdèk (a professional singer/dancer) and jaran képang, a cultural performance with ritual characteristics in which men dance on bamboo or leather horses. Of the Javanese musical traditions, gamelan music and terbangan music are now most common in Suriname. Javanese gamelan music in Suriname is one of the Javanese traditions that were clearly affected by its new environment. Since gamelan instruments were not brought to Suriname by the Javanese contract labourers, they had to be made from memory with the available Surinamese materials. Not all 'traditional' gamelan instruments could be remade and the sound of the 'new' gamelan instruments differs from their sound in Java. Finally, the Javanese martial art pentjak silat, which was at first only practiced in secret, has become very popular in Suriname among people of all ethnicities. $^{4}$

The combination of a relatively large Javanese community in Suriname that preserved (aspects of) traditional Javanese culture on the one hand, and the emergence of a theatre company that aimed to be multicultural Surinamese on the other, are the two elements that link this chapter to this book's theme of Dutch-Indonesian musical encounters. Music was not just an important element in the total theatre that the Doe-theatre company envisaged; it was also a means to including the diverse cultural traditions of different ethnicities into the company's new form of Surinamese national theatre. This chapter will explore the way in which the Doe-theatre's aim of being multicultural Surinamese was put to practice. Special focus will be on the extent to which Javanese cultural elements were embedded in the work of the Doe-theatre company. These explorations are based on what has been left of the Doe-theatre company: scripts, programmes and flyers, some audio, visual and audiovisual materials, and the recollections of former Doe-theatre members. This chapter does not offer a complete overview of Javanese elements in the work of the Doetheatre, rather it is a first attempt at tracing these elements.

4 The short profile on Javanese in Suriname in this paragraph is based on Parsudi Suparlan (1995); Hoefte (1990); and Gooswit (2010). 


\section{Multiculturalism and Javanese Elements in Doe Theatre's Compositions}

An obvious question that comes to mind when examining the multicultural Surinamese character of the Doe-theatre company is, who participated in it? Ideally, to give their productions a structural basis, Doelwijt and Tjon envisaged a steady core of eight to ten actors. In reality, the composition of the company would vary throughout the years due to a lack of financial means.

Doelwijt and Tjon first searched for members through a selection training. This training started on 1 October 1973. It was held three nights a week and lasted for three months. The promotional advertisement stated that Doelwijt and Tjon were looking for socially engaged and politically aware idealists. ${ }^{5}$ By the end of the training, sixteen aspiring actors and actresses from various ethnic backgrounds were selected. Twelve of them would actually participate in the Doe-theatre's first play Libi Span ini na ati foe Sranan (Life is bubbling in the heart of Suriname). While this production was still running, the Doe-theatre was hired by the Surinamese government to promote the political goal of independence. The year of government service that followed provided the Doe-theatre company with the financial stability it needed to practice theatre as a full-time profession and with a well-rounded cast. But although no contractual restraints were put on the Doe-theatre's artistic freedom, some tension arose as a result of which the government contract was ended in August 1975. According to Doelwijt and Tjon, the government could no longer handle the company's critical point of vue, which followed their own artistic conscience instead of official government views. ${ }^{6}$

After the government contract ended, the Doe-theatre company had to face a Surinamese reality: it was hard, if not impossible, to make a living out of acting. In 1976, the Doe-theatre made a new start as an independent company. ${ }^{7}$ At this time, the company had only one member left. After the commercially unsuccessful play Anansi kontra Masra Bobo, Masra Babari, Misi Fes'koki, Misi Sabiman nanga Masra Konflaw (The Spider versus Mister Pinhead, Mister Bigmouth, Miss Slavery, Miss Know-it-all and Mr. Faint) in 1976, René Recappé, the Doe-theatre's one remaining member, quit. It was only between 1977 and 1983 that the Doe-theatre company

\footnotetext{
5 'Thea Doelwijt en Henk Tjon beginnen theatertraining', De Ware Tijd, 27 September 1973 .

6 Doe-theatre's planning for 1980 and 1981, private archive Doelwijt.

7 'Oprichtingspamflet Doe-theater 1976', private archive Doelwijt.
} 
was able to establish a steady core. In 1977, three (aspiring) actresses joined the company. Mariëtte Moestakim and Mildred van Eer were selected during auditions, while Rieke Eersel, who had already been involved in theatre in the Netherlands, joined spontaneously. Together with Doelwijt and Tjon they would now form the core of the Doe-theatre company, albeit a much smaller core than the founders had hoped for. The always limited number of full-time members often forced the company to work with part-time and freelance employees. The musical accompaniment of the Doe-theatre plays was always provided by freelance musicians. However, among those musicians there were two, Walter Muringen and Harto Soemodihardjo, who worked with the Doe-theatre company throughout its existence. These men can therefore be said to have been vital members of the Doe-theatre company.

Ethnically speaking, the composition of the Doe-theatre company (including part-time and freelance members) was always diverse. The company was open and receptive to people from all cultural backgrounds who, in turn, found themselves attracted to the multicultural Surinamese ideal of the theatre company. However, when looking for a steady Doetheatre core - Doelwijt, Tjon, Moestakim, Eersel, Van Eer, Muringen and Soemodihardjo - it is clear that this core was predominantly of a Creole background. Still, two Javanese names stand out: Mariëtte Moestakim and Harto Soemodihardjo.

Mariëtte Moestakim joined the Doe-theatre company at the age of twenty. She had seen previous plays by the Doe-theatre company while still in high school. In 1977 Moestakim entered the Doe-theatre's selection training. According to the company's founders, it was immediately clear that Moestakim was a natural talent and she was hired. What attracted Moestakim most to the work of the Doe-theatre company was the socially critical tone. The multicultural aspect also appealed to her. The Doetheatre was the only theatre company in which all Surinamese could recognize themselves. Because of this, Moestakim felt that she could fit in with the company as well. Coming from the still fairly isolated Javanese community, this was a refreshing experience, although she thinks that because of her participation in the Doe-theatre company, she was probably seen as being 'vernegerd' (creolized) by more traditional Javanese. ${ }^{8}$

8 Mariëtte Moestakim's experiences as described here are based on an interview with Mariëtte Moestakim, Thea Doelwijt and Marijke van Geest, 17 December 2007 in Diemen and an interview with Mariëtte Moestakim and Thea Doelwijt, 9 October 2009 in Amsterdam. 
Harto Soemodihardjo first participated in a play by Doelwijt and Tjon during the aforementioned 1972 production Hare Lach, to which he was introduced by his friend Walter Muringen. Soemodihardjo's participation in the early plays, as well as in the Doe-theatre company, originated in his love of music. Soemodihardjo belonged to a Surinamese popular youth culture. Inspired greatly by American jazz, funk and pop music and icons like Stevie Wonder and Donnie Hathaway, Soemodihardjo played in several popular bands. He was less interested in traditional Javanese music. According to Soemodihardjo, his upbringing was not typically Javanese, but 'Surinamese'. He did participate in some Javanese events and, more or less unconsciously, was influenced by his Javanese heritage. But when speaking of traditional elements, Soemodihardjo claims to have been more interested in 'Surinamese' traditional music and, for example, drums. Yet, when composing music, to his own frustration he often found that something Javanese had 'crept in', even though he was trying so hard to be mainstream. Nowadays, Soemodihardjo embraces this influence, which he believes to be a culturally determined sense of melody and sound. ${ }^{9}$ But in his Doe-theatre days, even Doelwijt remembers that Soemodihardjo had no interest in traditional Javanese music. ${ }^{10}$

In a very literal sense, both Moestakim and Soemodihardjo provided the Doe-theatre company with a Javanese face. But instead of being driven by their Javanese background, they both seem to have been more a part of a creolized Surinamese popular youth culture. The driving force behind embedding Javanese and other traditional cultural elements was founder Tjon. All interviewed Doe-theatre members confirm this. ${ }^{11}$ After his return to Suriname in 1969, Tjon worked extensively with sociocultural organizations from all backgrounds. It infuriated him that there was almost no room for 'traditional' Surinamese cultures in official cultural life. ${ }^{12}$ For Tjon, traditional referred to the non-European cultures in Suriname, passed down for generations, but marginalized and considered inferior by the dominant European culture. Tjon resisted the European cultural dominance and fought to (re)instate non-European traditions as

9 Harto Soemodihardjo's experiences as described here are based on an interview with Soemodihardjo, 26 January 2009 in Rijswijk and a telephone interview with Soemodihardjo, 28 April 2010.

10 Doelwijt during the interview with Doelwijt and Moestakim, 9 October 2009 in Amsterdam.

11 A list of interviews with former Doe-theatre members is provided at the end of the article.

12 Interview with Henk Tjon, 8 April 2008 in Paramaribo. 
the basis of Surinamese culture. Through the theatre training Tjon created within the Doe-theatre company, he shared his knowledge of Surinamese cultures with the Doe-theatre members and often representatives and artists from various backgrounds were invited to give lessons. A working process evolved in which all members were able to produce 'cultural input' not only from their own cultural background, but from all backgrounds. Whenever Doelwijt wrote a draft script for a new play, elements would be added or altered through improvisation, after which Doelwijt would decide on the final version of the upcoming play. This way, with the help of like-minded artists and cultural representatives, Tjon pushed the Doe-theatre as a company to embed cultural elements of all Surinamese groups into its work, even at times when the Doe-theatre core was predominantly Creole.

The importance of the Doe-theatre training in the embedding of cultural elements presses for a closer look at the nature of this training. The training Tjon developed within the Doe-theatre company was consciously based on Surinamese cultural expressions and a Surinamese aesthetic. Using traditional songs, stories, instruments, dance, rhythm and rituals of all Surinamese population groups, the Doe-theatre members received lessons on theatre techniques, movement and ballet, vocal and musical expression, improvisation, text and character analysis and renowned plays and play writers. During trainings, Tjon often used the apinti drum as musical accompaniment. However, he also introduced the gamelan to Doe-theatre trainings. When asked about Tjon's use of the gamelan, neither Doelwijt nor Moestakim recall Tjon having had special training in this. According to both women, the musically talented Tjon created his own sound on the gamelan. He did not play the gamelan in a typically Javanese way, but used his extensive musical knowledge and love for rhythm to teach himself how to use the Javanese instrument in a more 'Surinamese' way. ${ }^{13}$ Soemodihardjo remembers that Tjon's inspiration to use the gamelan emerged when he was working with choreographer Marlène Lie A Ling, who combined classical ballet with folklore and traditional dance. Lie A Ling was also one of the experts that repeatedly participated in Doe-theatre trainings and productions. Soemodihardjo recalls that, at first, Tjon tried to play the gamelan in a traditionally Javanese way during trainings, but during plays it was always used in a non-conventional way. By using the Javanese gamelan in new ways an interesting musical

13 Interview with Moestakim and Doelwijt, 9 October 2009 in Amsterdam. 
encounter occurred: a mixed Surinamese sound was created on a Javanese instrument. A similar musical encounter also happened in reverse, when Doe-theatre musicians would mimic traditional Javanese or Hindustani sounds on European instruments such as the piano. ${ }^{14}$

Besides the use of the gamelan, Moestakim also remembers other specific Javanese elements used during trainings. There was traditional Javanese dance and lessons were given by Lie A Ling as well as by two choreographers who had studied traditional dance in Indonesia on a scholarship from the Indonesian embassy. In addition, there was the wellknown dancer and gamelan player Sagimin, an expert in the dances from the Ramayana epos. Other dance forms were taught by choreographers Mr. Ramdin (Hindustani), Ilse Marie Hajary (jazz) and Percy Muntslag (classical ballet). Another Javanese influence in Doe-theatre trainings, was the use of the Javanese martial arts pentjak silat. Pentjak silat was already fairly well-known in Suriname, as it is one of the Javanese cultural elements that found its way into mainstream Surinamese culture and was no longer practiced only by people of Javanese origin. Tjon believed that pentjak silat would help the actors and actresses achieve more balance between and control over body and spirit. ${ }^{15}$

During its almost ten year existence, the Doe-theatre produced seventeen plays. While it goes beyond the scope of this article to discuss all these plays individually, some general remarks can be made about the way in which traditional cultural elements were embedded in the Doe-theatre plays. Broadly speaking, the same kind of elements that were used in Doe-theatre company training sessions resurface in the Doe-theatre plays, ranging from language, movement, dance, music, musical instruments, customs and rituals of the different Surinamese population groups. However, two types of plays can be discerned in the work of the Doe-theatre company, in which cultural elements were used in distinctive ways.

First, in some plays the multicultural Surinamese aspect mostly functions as a part of the dominant socially critical tone. In these socially critical cabarets, ethnic division and diversity is just one of the recurring themes. Other recurring themes were politics, corruption, repression, economic development, poverty and migration. The Doe-theatre's

14 Telephone interview with Soemodihardjo, 28 April 2010.

15 Moestakim in the interview with Moestakim and Doelwijt, 9 October 2009 in Amsterdam. Moestakim has only a vague recollection of the names of the choreographers that studied Javanese dance in Indonesia. According to her, one went by the name of Pak Soenardi, while the other was named Sari Sajo or Kassan. 
desire to break away from the Surinamese ethnic affiliation is illustrated through explicit discussion of ethnic division, jokes and the use of common stereotypes. The message or ideal put forward by the Doe-theatre is one of nation building. In order to overcome other critical issues in Surinamese society, the divided Surinamese peoples would have to become one nation of Surinamese people, Srananman. Diverse cultural elements merged together in lyrics, décor, movement and music mainly serve to support this message.

In the second type of play produced by the Doe-theatre company the multicultural Surinamese character more or less functions as the central theme. These became presentations of Suriname's cultural richness. Customs and rituals of all Surinamese population groups are honoured and bound together in a storyline that leads to a similar conclusion, as was seen in the socially critical cabarets: the need for the peoples of Suriname to unite and together, as Srananman, build a new and prosperous Suriname. The storyline of these more dominantly cultural plays was often very similar. In general, these plays show how the different Surinamese population groups came to Suriname and what they had to suffer from Dutch colonial repression and divide-and-conquer-strategies. Due to colonialism, the Surinamese population has internalized a mentality characterized by repression and division. Now it is time to overcome these colonial remains through mutual understanding and respect and nation building. Cultural organizations of various backgrounds often participated in the production and performance of these plays. Doe-theatre members were expected to play all parts and participate in the cultural expressions of all origins, regardless of their own background. The way in which customs and rituals of all population groups were brought together on stage at the same time, representing parts of one harmonious whole, performed by peoples of all origins, was unique. In an interview with Tjon, he stressed the contrast between this way of presenting Surinamese cultures and the usual way, in which population groups were brought on stage separately in chronological order of arrival in Suriname. In Tjon's eyes, as well as in those of other Doe-theatre members, this was one of the most important accomplishments of the Doe-theatre company. ${ }^{16}$

In fact, the distinction between socially critical cabaret and cultural presentations was not as harsh as presented above. In some plays, the socially critical and the multicultural Surinamese aspect are more or less

16 Interview with Henk Tjon, 8 April 2008 in Paramaribo. 
balanced. Cultural elements of the various Surinamese groups - traditional songs, music, instruments, dance, movement, stories, rituals - were used in all Doe-theatre plays. A Javanese cultural element that was often used is the gamelan, usually not played in a traditionally Javanese way, except during the cultural presentations in which gamelan orchestras of a cultural organization participated. Another frequent Javanese element in the Doe-theatre plays are movements derived from Javanese dance, which were visible, for example, in dramatic movements with a slendang (a sort of scarf), and from pentjak silat. Although Dutch and the Surinamese language Sranantongo were the dominant language in Doetheatre plays, sometimes in the portrayal of rituals Sarnami Hindustani, Surinamese Javanese and even the indigenous Arowak and Caraib were used. The mention of Islam in the more dominantly cultural Doe-theatre plays can be seen as a shared Hindustani and Javanese influence, as some Hindustani and almost all Javanese in Suriname are Muslims. To add to this general image of the Javanese cultural and musical elements used in Doe-theatre plays, in the following some more specific examples will be explored.

\section{Libi span ini na ati foe Sranan (1974)}

Libi span ini na ati foe Sranan (Life is bubbling in the heart of Suriname) was the first play produced by Doelwijt and Tjon after founding the Doetheatre company in 1974. This play is a typical example of the second category of plays mentioned above. Libi span paid homage to Suriname's cultural diversity. It was performed by a multi-ethnic cast of twelve people selected during the 1974 selection training. To portray elements of the various Surinamese population groups, the Doe-theatre not only used its own texts and compositions but, with the help of representatives from various cultural organizations, also adapted traditional songs, texts and dance for use on stage. On stage, the various cultural elements were presented as parts of one Surinamese identity. ${ }^{17}$ The dominant language in Libi span was Sranantongo. Unlike in their previous plays, Dutch was not used at all. However, other non-European languages were used, namely Sarnami Hindustani, Surinamese Javanese and indigenous languages (Arowak and

17 'Libi Span ini na ati foe Sranan. Totaal-theater van Thea en Henk', De Ware Tijd, 26 June 1974 . 
Caraib). ${ }^{18}$ Although the use of traditional cultural elements and rituals on stage hardly ever led to feelings of indignation among the audience, in the case of Libi span the portrayal of Mama Sranan as a pregnant woman carrying the future Suriname, was considered inappropriate by Creole members of the audience. ${ }^{19}$

From the scripts retrieved of Libi span one learns that the play starts with the Creole story of Creation, which is accompanied by the sounds of the apinti drum. The story of how Anana created the world is followed by the appearance of Mama Sranan, the sacred mother of Suriname from Creole oral tradition. She recalls how the indigenous peoples used to live a happy life in a paradise-like Suriname. This story is illustrated with Javanese dance and gamelan music. When the Europeans arrived in Suriname, the carefree life of the indigenous peoples came to an abrupt ending. As new peoples were brought to Suriname from Africa and Asia, a repressed and divided society emerged. An indigenous requiem, sung in Arowak and Caraib and accompanied by indigenous instruments and dance, expresses the pain colonization has brought upon the indigenous as well as on the new 'Surinamese' peoples. During the second half of the play, all efforts go into overcoming the division in society and bridging the cultural gap between population groups. In this, gods of different Surinamese peoples are called upon for help. Together, God, Krishna, Tamoesi, Allah, Gado and Anana form the universal power of love that is needed to build a new and prosperous Suriname. ${ }^{20}$

In the actual performance of Libi span in all probability many more cultural elements of various groups were present. One can think of costumes, décor, music and movement. Unfortunately, the scripts that were found do not elaborate on this. However, it is clear that the Javanese population was represented in Libi span through the use of the gamelan, Javanese dance, the use of the Surinamese Javanese language in certain rituals and the call upon Allah for help.

$$
\text { Anansi kontra...(1976) }
$$

In the 1976 play Anansi kontra Masra Bobo, Masra Babari, Misi Fes'koki, Misi Sabiman nanga Masra Konflaw the socially critical and multicultural

\footnotetext{
18 Various scripts of Libi span ini na ati foe Sranan, private archive Doelwijt.

19 Interview with Henk Tjon, 8 April 2008 in Paramaribo.

20 Various scripts of Libi span ini na ati foe Sranan, private archive Doelwijt.
} 
Surinamese character of the Doe-theatre were more or less balanced. Manboi Anansi, son of the cunning spider Masra Anansi, is fed up with the destroying influence of the colonial past on Surinamese society. These remains are symbolized by the characters mentioned in the play's title: Masra Bobo (a foolish labourer), Masra Babari (a bawling overseer), Misi Fes'koki (a woman stuck in a slave mentality), Misi Sabiman (an arrogant and well-educated woman, who looks down on the mass) and Masra Konflaw (a drunken weakling). Lacking in all these characters is faith in the abilities of the Surinamese people. Manboi Anansi decides to put an end to this and, one by one, tricks all characters into his spider web. But as he is doing so, another enemy surfaces within himself: that of the powerhungry leader. Now the other characters, symbolizing the people of Suriname, have to find their common strength in order to beat the tyrant. ${ }^{21}$

The concept of Anansi kontra is based on the Creole oral tradition of the Anansitori, the stories about the cunning spider Anansi. Traditionally, in the telling of Anansitori there is a lot of interaction between the storyteller and his audience. To involve the audience more in the Doe-theatre's play about Manboi Anansi seats were created on stage, so that the audience could sit in a circle around the actors. ${ }^{22}$ The cast of Anansi kontra consisted of only two actors, Henk Tjon and René Recappé. Together, they played all six characters. The characters had distinctive masks, so that it was clear at all times which character was at play. These masks were made by visual artists Ron Flu and Paul Woei and were inspired by the masks used in Javanese theatre. ${ }^{23}$ The actors' costumes were inspired by indigenous clothing, while songs and music from all Surinamese cultures were used. This combination of an Anansitori, played by actors dressed in indigenous looking clothing, wearing Javanese-inspired masks and singing perhaps a Hindustani song, illustrates just how the Doe-theatre mixed separate Surinamese cultures into a new unified whole.

${ }^{21}$ Script found in private archive Doelwijt.

${ }^{22}$ Hadil, 'Anansi Contra: slaand applaus voor Henk Tjon c.s', De Ware Tijd, 25 August 1976.

23 'Oprichtingspamflet Doe-theater 1976', private archive Doelwijt; interview with René Recappé, 25 May 2008 in Paramaribo; interview with Ron Flu, 1 May 2008 in Paramaribo. 


\section{Prisiri Stari (1977)}

The same kind of cultural mix can also be found in the 1977 children's play Prisiri Stari (The Fun Star). This fairytale-like play was based on an indigenous legend in which, every once in a while, the moon descends down to the earth as a bird. While on earth, he plays with the children and looks for new stars to join him in his kingdom. During one of these nights the moon meets the indigenous girl Toewe. Toewe and her family live a traditional life in the Surinamese interior. When the moon tells her about his kingdom and all the stars in it, Toewe decides that she wants to become a star too. The moon agrees and takes the little girl back with him into the sky. There, Toewe becomes the Star of Suriname. Her task is to look out for the young new republic. Soon, Toewe finds that things are not going so well in Suriname. Her parents, Mese and Adoewe, have received a reward, because their daughter has become the star of Suriname. To collect their golden coconut, they leave the interior and travel to the city of Paramaribo. In Paramaribo, Mese and Adoewa are blinded by all the apparent wealth of the city. They do not want to go back to their traditional life and throw all their belongings into the river. Toewe does not understand how her parents could be so foolish as to believe that they could build a new, prosperous life without their own cultural heritage. Herein lies the message of Prisiri Stari: in order to build up Suriname, all Surinamese population groups and their heritage are needed (Doelwijt 1980).

In Prisiri Stari Javanese actress Mariëtte Moestakim played the leading character Toewe. The setting of this indigenous based play did not resemble an indigenous context at all. During the production of Prisiri Stari a Javanese visual artist by the name of Waïdi was in town. He was inspired by the play and offered to create its décor. Thus, Prisiri Stari's décor had a Javanese touch. Moestakim recalls how Waïdi made a gapura, a triumphal arch, from wood carvings and young palm leaves to represent the gate of heaven. The Prisiri Stari costumes were Javanese-inspired as well. For example, Moestakim and Doelwijt recall the head piece of King Moon in which the Indonesian garuda can be discerned as well as little wings attached to bracelets that the actors wore on the upper arm. ${ }^{24}$ The entire script of Prisiri Stari was written in Sranantongo, which makes for an interesting combination of indigenous, Javanese and Creole elements in the Doe-theatre company's first children's play.

24 Interview with Moestakim and Doelwijt, 9 October 2009 in Amsterdam. 
Na krakti foe Mama Sranan (1978)

After the Doe-theatre's year of government service in 1974-1975, the company only received incidental financial support from the government. This official support for the Doe-theatre's activities can mostly be attributed to the nationalist poet Robin Raveles, a government official and in the early 1980's even vice-minister of Culture. Raveles strove for a cultural policy that would contribute to turning his countrymen into confident, versatile Surinamese, who were strongly aware of the cultural richness of their people (Abrahams 2008: 143). His ambition was a good fit with the ambitions of the Doe-theatre company and its cultural performances, in which they included cultural elements of all population groups.

In this light, the Doe-theatre company was hired by the Surinamese government to produce a cultural manifestation in line with Libi span ini na ati foe Sranan on the occasion of the visit of the Dutch Queen Juliana to Suriname in February 1978. The result was the play $\mathrm{Na}$ krakti foe Mama Sranan (The power of Mother Suriname), which again celebrated Suriname's cultural richness and called for nation building. While the Doe-theatre produced and coordinated Na krakti foe Mama Sranan, several cultural organizations participated in it. These groups were Anna Nijaware Maro (indigenous), Tonelly (Creole), Sanskritiek Karkarini Samaadj (Hindustani) and Federatie Kebudajan Indonesia Suriname (Javanese). Although I was unable to retrieve a script of Na krakti foe Mama Sranan, the play's programme is all that is needed to conclude that this play too vividly incorporated the Doe-theatre's aim of a multicultural Surinamese identity. The programme notes the use of percussion instruments, song and dance from the various Surinamese ethnicities. It explicitly mentions the presence of religious figures such as a piaiman (indigenous), an obiaman (Creole/Maroon) and a Hindustani priest. The Hindustani priest calls upon Hanuman, the brave monkey god from the Ramayana epos, to fight a character called Kartasini. The presence of Hanuman raises the interesting question whether this mythical figure was at the time used as a Javanese, Hindustani or common cultural element, since the Ramayana epos is a part of both Hindustani and Javanese culture. Other specifically Javanese elements that can be deduced from the play's programme are the presence of a gamelan orchestra, Javanese clowns as they were known from the dagelan plays, Javanese dance movements and jaran képang. ${ }^{25}$

25 Programme of Na krakti foe Mama Sranan, private archive Doelwijt. 
In 1981, the Doe-theatre company was hired by the Surinamese government again. This time, Doelwijt and Tjon were asked to lead the Surinamese delegation to the Caribbean arts festival Carifesta on Barbados. The Surinamese delegation to Carifesta consisted of experts in the field of theatre, traditional and contemporary music, dance and visual arts. The delegation shared the common theme 'rebirth', a referral to the 'rebirth' Suriname supposedly experienced through the 1980 military coup. The Doe-theatre company translated this theme into a theatrical manifestation of Surinamese cultural richness, called Rebirth. For this occasion, the Doe-theatre company consisted of Thea Doelwijt, Henk Tjon, Rieke Eersel, Mariëtte Moestakim, Walter Muringen, Harto Soemodihardjo, Wilgo Baarn, Chandra van Binnendijk, Marlène Lie A Ling, Otto Manichand and Alida Neslo. They were, however, not the only participants in Rebirth. Like in Na krakti foe Mama Sranan various cultural organizations took part. These were Anne Nija Mare Waro (indigenous), Vanda Libi (Maroon), Naks (Creole), Pemuda-Timbol (Javanese) and Kalamitri (Hindustani). In addition, members of the Surinamese National Ballet, the Surinamese Dance Theatre and Harto [Soemodihardjo]'s Band participated in Rebirth.

As no script of Rebirth was found, the use of cultural elements has to be deduced from other sources. From the members recollections, it seems that Rebirth had its own distinctive storyline. Within this storyline, very similar cultural elements were used, as had been the case in Libi span ini na ati foe Sranan and Na krakti foe Mama Sranan. However, in Rebirth the use of Hindustani elements seems to have been more prominent than it was before. At the beginning of the play, a couple gets married in a Hindustani wedding ceremony. After the ceremony, the newlyweds are confronted with a great many obstacles. Traditions and rituals from the various Surinamese cultures turn out to be of crucial importance in overcoming these obstacles. ${ }^{26}$ Where the programme of $\mathrm{Na}$ krakti foe Mama Sranan showed the kind of elements used, photographs of Rebirth were printed in the book De grote Caraibische familie (The big Caribbean family) (Doelwijt, Beeker and San-A-Jong 1981), in which the Surinamese Carifesta participants described their experience. These pictures show the return of the mythical character Hanuman, the use of movements from

26 This very restricted description of Rebirth was deduced from various interviews with former Doe-theatre participants. 
the Javanese martial art pentjak silat, and a character whose costume and position somewhat resemble the exterior of a Javanese wayang puppet.

The extensive use of Hindustani elements in Rebirth, which can also be seen in the printed pictures, surprised contemporary critics. In De Ware Tijd Benjamin Mitrasingh wrote that it required real guts to include religious aspects of all groups in one play, considering that this was a sensitive subject in Suriname. In particular, the extensive use of Hindustani culture was extraordinary, since the Hindustani community was thought fairly isolated and kept to itself. ${ }^{27}$ In Rebirth it was presented on stage as a part of daily life. According to another critic, H.R.A. Malmberg, Rebirth expressed the Surinamese integration process of the various population groups into national unity as a step in the gradual cultural decolonization of Suriname. ${ }^{28}$

\section{The Reception and Audience of the Doe-theatre}

To understand how successful the Doe-theatre company was in accomplishing a multicultural Surinamese character, we must look beyond the Doe-theatre's composition, training, plays and performances. It is also interesting to see to what extent the Doe-theatre company was able to reach a multicultural Surinamese audience. While Doelwijt and Tjon had at one point intended to reach a broad national audience, this was generally not achieved. Instead, the Doe-theatre's regular performances in Paramaribo attracted the usual middle and higher class audience from a Creole and mixed background. According to Moestakim, one of the biggest difficulties in reaching a Hindustani and Javanese audience was that many of them still lived outside of central Paramaribo. ${ }^{29}$ In general, the city audience was enthusiastic about the Doe-theatre plays, which were sold out most of the time.

There are exceptions to the limited reach of the Doe-theatre company. On several occasions, especially while in government service, the Doe-theatre was able to go on a tour through the districts and the Surinamese interior. Such tours were rare in Suriname, as these areas were

\footnotetext{
27 Benjamin Mitrasing, 'Inbreng Carifesta op niveau', De Ware Tijd, 8 July 1981.

28 H.R.A. Malmberg, 'Rebirth in perspektief van de kultuurpolitiek in Suriname', De Ware Tijd, 22 July 1981.

29 Moestakim in interview with Moestakim and Doelwijt, 9 October 2009 in Amsterdam.
} 
hard to reach and the people who lived there could not afford to pay for theatre visits. With its performances in the districts and the interior, as well as through special performances for schools within Paramaribo, the Doe-theatre company reached an audience of a broader ethnic and socioeconomic scope. Through the Doe-theatre's performances outside of Paramaribo, especially in a district like Commewijne, the theatre company was also able to reach a Javanese audience. While the audience in Paramaribo was enthusiastic about the Doe-theatre plays, the audience outside of the city was even more thrilled. On the one hand, this excitement probably had to do with the fact that there was little entertainment in these areas. On the other hand, the fact that the people outside of Paramaribo recognized elements from their own culture and religion in the plays of this city theatre company was a pleasant surprise. Furthermore, the presence of unfamiliar cultural elements was intriguing to the people in these isolated areas. According to Tjon, the Doe-theatre's performances outside of the city were a great encounter, especially in the interior where Javanese and Hindustani cultural elements were new to the indigenous and Maroon population. ${ }^{30}$ The company's message of nation building seems to have been understood outside of the city as well. Daily newspaper De Ware Tijd recorded the words tribal chief Forster in the Marroon village Langetabbetje spoke after a Doe-theatre performance: 'Wi alamala na Srananman. Wi moes libi boen nanga makandra. We moeten samen leven, samen werken voor Suriname', ${ }^{31}$

The Doe-theatre's audience was also broadened by the company's performances in the Caribbean region (Barbados, St. Lucia, Curacao) and in Europe (the Netherlands, France, Germany, Belgium). Opinions on the Doe-theatre plays were more differentiated in the Netherlands than they were in Suriname. The general response was positive, although plays did not always live up to the expectations or standards of the Dutch critics. While the socially critical tone of Doe-theatre plays was very sharp and eventually even dangerous in the Surinamese context, in the Netherlands it was considered relatively meek. The multicultural aspect of Doe-theatre's plays left critics with a sense of incomprehension. Although all phrases were repeated in Dutch, the use of Sranantongo made them uneasy, as they felt they were missing something. In a way, the incomprehension

30 Interview with Henk Tjon, 8 April 2008 in Paramaribo.

31 'Libi Span in districten en binnenland', De Ware Tijd, 17 August 1975. 'We are all Srananman. We have to live well together. We have to live together, work together for Suriname.' 
Dutch critics expressed about a play like Libi span indicates that the Doetheatre company had created its own Surinamese theatre form. On the one hand, some Dutch critics thought that this was no more than a manifestation of folklore, unsuited to an audience outside of its own region. In the Amsterdam-based newspaper Het Parool, H. van den Berg expressed the opinion that Libi span was no more than a series of extremely primitive scenes with very basic use of expression, music, song and dance. ${ }^{32}$ Other critics were more receptive toward this new form of Surinamese theatre and emphasized that it could not be judged by Western standards. In NRC Handelsblad, Hanny Alkema wrote that the Dutch audience, from its own 'civilized' arrogance, expected Surinamese theatre to be an exciting package of primitive elements ('rolling drums, jungle sounds, wild dances and many nude brown breasts'). ${ }^{33}$ Instead, this theatre company had started a slow but intensive search for a distinctive Surinamese character and a sophisticated national theatre form. ${ }^{34}$

The Doe-theatre company enjoyed much popularity in Suriname and there is no doubt that its work and mentality influenced and inspired people. However, an interesting question for future research would be to which extent it has had a lasting influence on Surinamese theatre as a whole. The Doe-theatre company, as a socially critical, multicultural and professional steady theatre company, seems to have been a unique phenomenon in Surinamese cultural history that has had no clear successor. Regarding any lasting influence of the Doe-theatre's social criticism, the statement of actrice Rieke Eersel about the satirical portrayal of Surinamese parliament as monkeys in 1977 seems to be characteristic: it was a hilarious thing to do and watch, but to this day nothing has changed. ${ }^{35}$

\section{Conclusion}

This chapter has explored the way in which the Doe-theatre's aim of being multicultural Surinamese was put to practice and, specifically, the extent to which Javanese cultural elements were embedded in the work

32 H. van den Berg, 'Surinaamse Doe Groep in Amsterdams Mickery theater. Bont gewoel in show', Het Parool, 16 April 1975.

33 Hanny Alkema, 'Surinaams theater gaat zijn eigen gang', NRC Handelsblad, 16 April 1975 .

34 Jan Paul Bresser, 'Surinaamse Doe-Groep in Mickery. Theater op zoek naar eigen verstaanbaarheid', De Volkskrant, 17 April 1975.

35 Interview with Rieke Eersel, 15 April 2008 in Paramaribo. 
of the Doe-theatre company. It has shown how, through a group process and often on the basis of opportunity, the Doe-theatre company made structural use of diverse cultural elements to raise awareness and mutual understanding and to promote an ideal of nation building. Structurally recurring Javanese elements that were used in both the theatre training and the Doe-theatre plays are the use of the gamelan, movements from Javanese dance and martial arts, the mythological character Hanuman, Islam and the Surinamese Javanese language. The various cultural elements were used in an interchangeable way in the sense that where Javanese elements were used, similar indigenous or Hindustani elements could have been used with the same effect. They were not meant to accurately depict Surinamese cultures in all their traditional aspects, but used in a stylized way as a sign of inclusion. In line with this, for example, the gamelan was frequently used not to make Javanese music, but rather to create new Surinamese sounds with a Javanese touch. Although the Doetheatre company remained predominantly Creole in its core, inspired most by Tjon's passion for cultural diversity, it went to great lengths to incorporate other Surinamese cultures into its work. The Doe-theatre's use of cultural elements from different Surinamese backgrounds created an extraordinary encounter of cultures on stage. In this, the Doe-theatre company was unprecedented in Suriname.

\section{References}

Abrahams, Cynthia. 'Robin “Dobru” Raveles. De dichter', in: Rosemarijn Hoefte, Peter Meel and Hans Renders (eds.), Tropenlevens. De (post)koloniale biografie, pp. 126-147. Leiden: KITLV Uitgeverij; Amsterdam: Boom, 2008.

Doelwijt, Thea. Prisiri Stari. Wan komedi-pré gi pikin / De pretster. Een theaterspel voor kinderen. Paramaribo: Eldoradoboek, 1981.

Doelwijt, T., K. Beeker and C. San-A-Jong (eds.). De grote Caraibische familie: Een ooggetuigeverslag van het Caraibische kunstfestival Carifesta IV, Barbados, 19 juli-3 augustus 1981. Paramaribo: Ministerie van Cultuur, Jeugd en Sport in Suriname, 1981.

Gooswit, Sylvia M. Van tembang tot jaran képang: Traditionele Javaanse zang, muziek en dans in Suriname. Paramaribo: Afdeling Cultuurstudies van het Ministerie van Onderwijs en Volksontwikkeling Paramaribo, 2010.

Hoefte, Rosemarijn. 'Beeldvorming Javaanse cultuur', Oso 9-2: 7-18, 1990.

Kempen, Michiel van. Een geschiedenis van de Surinaamse literatuur. Breda: De Geus, 2003 .

Ockhorst, Annika. 'S.O.S. W'e g'a fesi. Een onderzoek naar de weerspiegeling van de Surinaamse samenleving in het werk van het Doe-theater, 1970-1983'. MA thesis, Leiden University, 2009.

Ockhorst, Annika, with Thea Doelwijt. Lachen, huilen, bevrijden: De weerspiegeling van de Surinaamse samenleving in het werk van het Doe-theater, 1970-1983. Leiden: KITLV Press, 2012. 
Suparlan, Parsudi. The Javanese in Suriname: Ethnicity in an ethnically plural society. Tempe, Ariz: Program for Southeast Asian Studies, Arizona State University, 1995.

\section{Collections}

Private archive of Thea Doelwijt, Amsterdam.

Private archive of Marïette Moestakim, Diemen.

\section{Interviews $^{36}$}

Wilgo Baarn (Paramaribo, 07-05-2008); Chandra van Binnendijk (Paramaribo, 20-05-2008); Oswaldo Braumuller (Paramaribo, 09-05-2008); Borger Breeveld (Paramaribo, 13-05-2008); Hans Breeveld (Paramaribo, 20-05-2008); Joan Buitendorp (Amsterdam, 27-02-2009); Thea Doelwijt (Amsterdam, 23-10-2007, 14-11-2007, 30-01-2008, 27-02-2009, 20-07-2009); Thea Doelwijt (Paramaribo, 08-05-2008, 22-05-2008); Thea Doelwijt, Marijke van Geest and Percy Muntslag (Den Haag, 17-01-2008); Thea Doelwijt, Marijke van Geest and Mariëtte Moestakim (Diemen, 17-12-2007); Thea Doelwijt and Mariëtte Moestakim (Amsterdam, o9-102009); Mildred van Eer (Paramaribo, 21-05-2008); Rieke Eersel (Paramaribo, 15-04-2008); Frank Faverey (Paramaribo, 17-04-2008); Ron Flu (Paramaribo, 01-05-2008); Marlène Lie A Ling (Paramaribo, 21-05-2008); Hugo Ment (Paramaribo, 30-04-2008); Mariëtte Moestakim (Diemen, 13-04-2009); Walter Muringen (Paramaribo, 24-05-2008); René Recappé (Paramaribo, 25-05-2008); Harto Soemodihardjo (Rijswijk, 26-01-2009 and via telephone on 28-04-2010); Henk Tjon (Paramaribo, 08-04-2008, 15-05-2008).

\section{Newspapers}

De Volkskrant

De Ware Tijd

Het Parool

NRC Handelsblad

${ }^{36}$ Most of these interviews were conducted during the research for my MA thesis. General statements about the Doe-theatre company made in this article are often deduced from common statements by former Doe-theatre company members in these interviews. 